\title{
White Collar Criminals: The State of Knowledge
}

\author{
T. Alalehto* \\ Department of Sociology, Umea University, Umea, Sweden
}

\begin{abstract}
White collar crime is the least studied and the least understood crime type in comparison to traditional crime types. This review highlights the recent developments in the state of knowledge over the white collar criminals. The review concerns the topics of demography, motivation for offending and career criminality among white collar criminals. It compiles the international results (mainly West-European) so far in the three topics. The review ends with a request on further research that needs to be done in four aspects: what is the main demographic difference between white collar offenders and confirmative non-offenders? How can we explain the difference in the age-crime relationship between street criminals and white collar criminals? Why do we still have the gender divergences by white collar criminals, despite the fact that women increase their participation into the labor market? And why do we know so little about the criminal motivation among white collar criminals?
\end{abstract}

Keywords: Career criminality, motivation, socio-demography, white collar crime.

\section{INTRODUCTION}

White-collar crime has been handled primarily as an odd phenomenon in the history of criminology, which, in retrospect, is a rather surprising position. In 1907 Edward Ross (1973) described moral decay within the US where 'criminaloid' leaders were poisoning, polluting, and imperiling the security of thousands of people just for their own success. This was followed up just a few years later, in 1913 by Willelm Bonger (1969) in his critique of capitalism where he described capitalism itself as a breeder of egoism that was directly opposed to the natural human trait of altruism, especially in the market where the majority of people are exploited in order to generate profit for the exploiters. And last, but not the least, the critical statements of Edwin Sutherland (1940) in 1939 warned that white collar crime violated trust, created distrust, lowered social morale, and produced disorganization within social institutions. Thus, white-collar criminality was described as being more damaging to society than the damage caused by street criminality. ${ }^{1}$

\footnotetext{
${ }^{1}$ Sutherland also introduced the general definition of white collar crime: "White collar crime may be defined approximately as a crime committed by a person of respectability and high social status in the course of his occupation." (Sutherland, 1985:7), which stood out as the general ground for empirical studies of white collar crime in decades. But a general problem with Sutherland's definition was that it included social status as a variable limiting its empirical openness to other possible levels of social status. A competitive definition of white collar crime was then proposed by Edelhertz: "an illegal act or series of illegal acts committed by non-physical means and by concealment or guile to obtain money or property, to avoid the payment or loss of money or property, or to obtain business or personal advantage." (Edelhertz, 1970:3). Edelhertz definition has over time been more accepted in the research agenda of white collar crime (e.g. T. Alalehto
}

*Address correspondence to this author at the Department of Sociology, Umea University, Umea, Sweden; Tel: 46907866694; Fax: 4690785490;

E-mail: tage.alalehto@umu.se
The damage caused by white collar crime has been discussed in terms of social harm where ordinary people are negatively affected by a sense of alienation (Meier \& Short, 1995), especially when it concerns large frauds carried out by privileged white males (Weisburd, 1991:83). Citizens in general rate being victimized by white collar crime more frequently and seriously than street crime (Braithwaite, 1985), and this is especially the case among elderly people and women (Larsson \& Alalehto, 2013; The 2005 National Public Survey on White Collar Crime, 2006). In economic terms, the damage of white-collar crime during the 1970s in Sweden was around 5-20 billion SEK as compared to 0.35 billion SEK for street crime (Brå, 2003). This value increased to nearly 130 billion SEK for white collar crime in Sweden at the beginning of 2000 (Ekobrottsmyndigheten, 2005). In the US, the damage from white collar crime was estimated to be 200-600 billion USD as compared to 3-4 billion USD for street crime during the 1990s (Schnatterly, 2003). The current cost of white collar crime in the US is 404 billion USD compared to 20 billion USD caused by street crime (Pardue, et al, 2013a; see also Coleman, 1998). In other words, the economic losses are between 17 and 32 to 1 for white-collar crime as compared to street crime (Ivancevich, et al, 2003; see also Trahan, et al, 2005). Despite these demonstrations of harmfulness and economic damage, white-collar crime is still more or less viewed as a deviant case in criminology (Weisburd, et al, 2001; Benson, 2002).

Much of this historical disinterest rests on the fact that white-collar crime has been traditionally studied by

\& Larsson, 2012; M. Benson \& Simpson, 2009; Wheeler, Weisburd, Waring, \& Bode, 1988). In any way I will present results from empirical studies based on Sutherlands and Edelhertz definition because overall the two definitions are more similar than different concerning other sociodemographic aspects. 
sociologists and thus disregarded as a criminological matter in criminology as a field of its own right. Critical nonlegalistic, radical-oriented, and qualitative label-oriented sociologists in America (e.g. Simon, 1999) and Britain (e.g. Punch, 1996) broadened the phenomenon to explicitly emphasize the investigation of power, influence, and trust by powerful groups involved in immoral, but not necessarily illegal, acts (Braithwaite, 1985; Schlegel \& Weisburd, 1994). This lack of a criminality perspective was also because critical sociologists inspired sociologists of deviance to further blur the distinctions between illegal acts and other stigmatized behaviors (alcohol abuse, gambling, homosexuality, etc.) by powerful groups. The consequence was that white collar criminality ended up in a scientific no man's land (Croall, 2001; Nelken, 2002; Simpson \& Weisburd, 2009).

But things began to change during the 2000s with highly cited work investigating white collar crime in the field of criminology (Alalehto \& Persson, 2013). This research was associated with an increasing number of empirical investigations, and not just those focusing on egregious, media attended, and largely atypical cases (Benson \& Moore, 1992). The main focus of these investigations was to determine the characteristics of the average white-collar criminal. At the same time, this research reshaped the understanding of earlier results in the field of white collar crime concerning topics such as theoretical developments, punitiveness, prevention, and control (Simpson, 2013).

In this article, we discuss the current state of knowledge concerning demography, motivation, and career criminality among white-collar criminals. One characteristic that makes white collar criminals of particular interest in the field of criminology is that these people of high socioeconomic status are not ordinarily associated with crime (Poortinga, et al, 2006; Soothill, et al, 2012; Weisburd et al., 2001). Thus, they serve as an anomaly in the field by not taking the route of criminal thinking or a criminal lifestyle. Instead, they try to form relationships with other persons or professions that should protect them from developing a criminal identity (Walters \& Geyer, 2004). Therefore, one aspect that has to be discussed is the idiosyncratic functions of antisocial conduct among white collar criminals compared to street criminals (DeLisi \& Piquero, 2011). This discussion demands that white collar criminals should be investigated as objects for developmental and life-course approaches in order to follow the trajectories of their criminal careers (Piquero \& Benson, 2004). This aspect is still underdeveloped in research on white collar crime compared to research on street criminality (Benson, 2013), although there are a few exceptions (Menard, et al, 2011; Onna, et al, 2014; Weisburd m.fl., 2001).

Another aspect that needs to be investigated is the predicted prevalence of white-collar crime in the future. Several investigations by social scientists exploring social group mobility show that white collar professions in Western European economies increase due to increases in educational level, overall economic development, immigration waves, and democratic traditions (e.g. Esping-Andersen \& Wagner, 2012; Hout, 2010; Yaish \& Andersen, 2012). These factors are suspected to lead to an increase in white-collar criminality in Western European countries (Benson, 2002).

Based on the historical context of criminology research, important questions to answer are who is the typical white collar criminal? What is known about white-collar crime motivation? And what are the differences between career criminals and one-time offenders? However, the currently available research is not able to explain the phenomenon completely, at least not at the same level as the explanations for street criminality. The project of white-collar crime research is still a descriptive project, but to be able to explain a phenomenon we have to describe the phenomenon by providing the 'facts' with the highest empirical precision possible. Thus there is a need to provide an overall description of the specific qualities that characterize white collar criminals today (Benson, 2013; Poveda, 1994).

\section{WHITE-COLLAR CRIME: A GLOBAL OVERVIEW}

Investigations into the white-collar criminal are not yet a fully global research enterprise. However, this research has begun to expand beyond its historical concentration in Anglo-American countries (the US and the UK) by extending quantitative and qualitative data sampling to several other countries, including Germany (Blickle, et al, 2006; Cleff, 2013), Austria (Noll, 2014), the Netherlands (Onna et al., 2014), Italy (Merzagora, et al, 2014), Sweden (Alalehto \& Larsson, 2008, 2012; Ring, 2003; Kardell \& Bergqvist, 2009), Norway (Gottschalk, 2013; Gottschalk \& Glasø, 2013), Finland (Häkkänen-Nyholm \& Nyholm, 2012; Kankaanranta \& Muttilainen, 2010), Israel (Shechory et al., 2011), Australia (Freiberg, 1992; Duffield \& Grabosky, 2001), Canada (Gagnon, 2008; Ouimet, 2011; Paquette, 2010), and China (Deng, Zhang, \& Leverentz, 2010). But, of course, much of the research has still been performed in the UK (e.g. Croall, 1989; Croall, 1992; Levi, 1993; Levi, Burrows, Fleming, \& Hopkins, 2007; Slapper \& Tombs, 1999) and the US (e.g. Coleman, 1987; Pontell \& Calavita, 1993; Shover \& Hochstetler, 2006; Vaughan, 1983; Wheeler, et al, 1988).

Most of the investigations have been case studies or cross-sectional studies (e.g. Alalehto \& Larsson, 2012; Kankaanranta \& Muttilainen, 2010; Vaughan, 1983). There have only been a few longitudinal investigations (Holtfreter, Beaver, et al, 2010; Weisburd, 1991; Lewis, 2002; Soothill et al., 2012; Weisburd et al., 2001; Onna et al., 2014), idiosyncratic investigations (Benson \& Walker, 1988; Benson \& Moore, 1992; Kerley \& Copes, 2004; PWC, 20012012; Ring, 2003) and comparative investigations, which have mostly compared countries in Europe (Alalehto \& Larsson, 2008, 2012; Bussmann \& Werle, 2006; Karstedt \& Farrall, 2007). In addition to these investigations, there have also been global surveys conducted by forensic accounting firms such as PwC, KPMG, and Deloitte.

\section{Demography}

Around $80 \%$ of white collar criminals are men (Benson, 2002; Bussmann \& Werle, 2006; Kardell \& Bergqvist, 2009; Ring, 2003; Wheeler et al., 1988; Weisburd, 1991; Weisburd et al., 2001; Gottschalk \& Glasø, 2013), and this mirrors the general gendered occupational division in society where 
women tend to have lower-level positions than men (Deng et al., 2010; Ring, 2003; Gottschalk \& Glas $\varnothing$, 2013; Steffensmeier, et al, 2013). However, this pattern depends on what level of crime we look at. If the white-collar crime is of low complexity (so-called pink-collar crimes such as asset misappropriation, corruption, fraudulent statements, embezzlement, etc.) then the sex ratio is more balanced compared to more complex crimes such as antitrust violations, security fraud, etc. (Wheeler et al., 1988; Dodge, 2008; Lewis, 2002; Holtfreter, 2005; Poortinga et al., 2006; Weisburd, 1991; Gottschalk \& Glasø, 2013).

The mean age of white collar criminals is around 40-45 years (Wheeler et al., 1988; KPMG, 2011; Weisburd, 1991; Weisburd et al., 2001; Benson, 2002; Holtfreter, 2005; Poortinga, 2006; Bussmann \& Werle, 2006; Alalehto \& Larsson, 2008; Kardell \& Bergqvist, 2009; Ring, 2003; Soothill et al., 2012; Kerley \& Copes, 2004; Gottschalk, 2013; Onna et al., 2014). The explanation for this is similar to the gendered division, younger people have not had the same opportunity to start a business or establish themselves in the labor market so as to engage in white-collar crime to the same degree as middle-aged people (Ring, 2003).

The majority of white collar criminals belong to the ethnic majority in the country (Alalehto \& Larsson, 2008; Benson, 2002; Daly, 1989; Kardell \& Bergqvist, 2009; Kerley \& Copes, 2004; Klenowski, Copes, \& Mullins, 2010; Poortinga et al., 2006; Walters \& Geyer, 2004; Weisburd, 1991; Wheeler et al., 1988). However, ethnicity is a variable that shows some contextual variation at least between Sweden and the US where non-white white collar offenders are treated more harshly than white-collar offenders in the sentencing process (Benson \& Walker, 1988). This observation is contradicted by the observation that white collar offenders of high social status tend to be treated more harshly than other categories of white collar offenders (Weisburd, 1991), but this itself is indirectly criticized by the observation that ethnic minorities are treated equally with the ethnic majority group when it comes to white collar crime (Ring, 2003). This situation is distinctly different from that of non-white collar offences where belonging to an ethnic minority has a significantly greater effect on the person's ability to become employed after their incarceration (Kerley $\&$ Copes, 2004).

White collar criminals tend to be married (Benson, 2002) and this means that there are responsibilities for family care before, during, and after conviction (Klenowski et al., 2010). The recidivist rates are very low for married white collar offenders (Weisburd et al., 2001), but at the same time there is a higher divorce rate among white collar criminals (Klenowski et al., 2010) than among street criminals (Weisburd, 1991; Walters \& Geyer, 2004) or among the general population (Ring, 2003; Alalehto \& Larsson, 2008). In the past when divorce was not as acceptable as it is today, a frustrated and unhappy marriage could lead a potential offender into a state of depression, exhaustion, or indifference that could lead to the criminal behavior (Riemer, 1941). Female offenders have been shown to be more overrepresented by divorce and family caretaking (Daly, 1989; Haantz, 2002; Shechory, et al, 2011) than male offenders.
The white-collar criminal's criminal history varies depending on what type of crime the offender has been convicted of. Those who have been convicted of antitrust violations generally have no previous prosecution compared to those convicted of credit card fraud, false claims, mail fraud, or tax evasion where half of all offenders have a previous conviction (Benson, 2002; Benson \& Moore, 1992; Ring, 2003; Onna et al., 2014; Ragatz \& Fremouw, 2010; Weisburd et al., 2001; Wheeler et al., 1988). In general, white collar criminals are characterized by low-rate criminality (having an average of $1-3$ convictions) (Alalehto \& Larsson, 2008; Benson, 2002; Holtfreter, et al, 2010; Kerley \& Copes, 2004; Soothill et al., 2012). However, there are exceptions to these general results depending on whether the offender begins his or her criminal career in white collar criminality or street criminality (Lewis, 2002; Onna et al., 2014). If the offender mixes their crimes with street criminality (especially if the first crime is a street crime and then this is mixed with white collar crime) then the offenders tend to be more often men and of equal ethnic distribution and a significantly younger mean age compared to pure white collar offenders (Lewis, 2002). Female offenders are less likely to have prior convictions despite the fact that they commit a greater number of low-complexity white collar crimes than men (Wheeler et al., 1988; Ring, 2003). Although they are convicted less often, women are charged with crimes significantly more often than men (Lewis, 2002).

In general, white-collar criminals have regular incomes according to their occupations as employers or in a typical middle class profession (Alalehto \& Larsson, 2008; Gottschalk \& Glasø, 2013; Kerley \& Copes, 2004; Onna et al., 2014; Riemer, 1941; Ring, 2003). However, the regularity of income and job stability vary depending on what level of crime the offender has been convicted of (Wheeler et al., 1988; Kardell \& Bergqvist, 2009), the crime type of low or high complexity (Weisburd et al., 2001; Gottschalk, 2013), the income distribution among employers (Ring, 2003; Onna et al., 2014), and whether the offender belongs to an ethnic minority, the number of prior arrests, the age of onset of the criminal behavior (arrested or incarcerated before 24 years of age), and the total time sentenced (Kerley \& Copes, 2004).

White collar criminals exhibit equal or lower unemployment rates compared to the general public and especially to street criminals (Alalehto \& Larsson, 2008; Benson, 2002; Weisburd, 1991; Weisburd et al., 2001; Poortinga et al., 2006; Kardell \& Bergqvist, 2009; Ring, 2003). However, this does not apply to all kinds of white collar crime, for example, those convicted of antitrust violations have $0 \%$ unemployment while those convicted of mail fraud have 25\% unemployment (Wheeler et al., 1988; Weisburd, 1991; Weisburd et al., 2001). White collar criminals own their own homes to a similar degree as the general population and to a much greater degree than street criminals (Wheeler et al., 1988; Weisburd, 1991; Weisburd et al., 2001; Benson, 2002; Ring, 2003). Their education level ranges from the same to greater than the general population, and this depends on what type of white collar crime the offender has been convicted of (Alalehto \& Larsson, 2008; Bussmann \& Werle, 2006; Wheeler et al., 
1988; Weisburd, 1991; Weisburd et al., 2001; Poortinga et al., 2006; Kardell \& Bergqvist, 2009; Schoepfer \& Piquero, 2006; Benson \& Moore, 1992; Soothill et al., 2012; Walters $\&$ Geyer, 2004).

In general, the white collar criminal shows a higher level of socioeconomic status in terms of prestige, income, and education than the general public (Bussmann \& Werle, 2006; Wheeler et al., 1988; Weisburd, 1991; Weisburd et al., 2001; Soothill et al., 2012; Gottschalk \& Glas $\varnothing, 2013)$. This socioeconomic status is often inherited by the offender's father's socioeconomic position as an employer (Ring, 2003).

Compared to street criminals, white collar criminals show just one half $(25 \%)$ the number of adaptations or learning problems during their education and less than half the number of problems with social adjustment (21\%) (Benson, 2002; Weisburd et al., 2001). Adaptions and adjustment problems are especially common among those white-collar offenders who have admitted to or been convicted of low complexity crimes such as mail fraud and false claims (Benson \& Moore, 1992), credit card fraud and check fraud (Holtfreter et al., 2010), and career offenders (Weisburd et al., 2001). Around 6\% to $10 \%$ of white-collar criminals have been abused or neglected as a child and around $6 \%$ to $10 \%$ have reported that they have one or more criminal family members or friends. However, this is significantly less than what street criminals report, which is around $17 \%$ to $20 \%$ reporting abuse or neglect and $18 \%$ to $20 \%$ having a criminal family member or friend (Benson, 2002; Kerley \& Copes, 2004; see also Shechory et al., 2011).

In general, white collar criminals suffer from at least one emotional, marital, or substance abuse problem over the course of their lives (Weisburd, 1991; Soothill et al., 2012). Around 7\% of low-frequency offenders have problems with drug abuse and around 5\% have alcohol abuse problems. For career offenders, however, these numbers are much higher with about 20\% reporting drug abuse and 9.5\% reporting alcohol problems (Weisburd et al., 2001, see also Onna et al., 2014). In a comparative study of a sample of embezzlers (a low complexity crime) the offenders had a higher rate of substance abuse than the general population but only onefourth the rate of substance abuse as non-violent street criminals (Poortinga et al., 2006). An interesting issue with regard to health problems among white-collar criminals is the observation that tax evaders in Sweden have a slightly higher mortality rate than the general population. This difference is also clearly gendered, were convicted female tax offenders have a $2 \%$ higher mortality rate than both the general population and male tax offenders (Ring, 2003).

White collar criminals tend to be more religious than street criminals (Benson, 2002) but less so than the general population (Alalehto \& Larsson, 2008). In addition, white collar criminals tend to vote less often than the general public (Schoepfer \& Piquero, 2006). White collar criminal's financial assets vary significantly according to gender (Gottschalk \& Glasø, 2013) and depend on what kind of crime the offender has been convicted of (Weisburd, 1991; Weisburd et al., 2001; Benson, 2002; Onna et al., 2014). For example, antitrust violators tend to have significant financial assets compared to embezzlers, but embezzlers in general have about three times greater financial assets than street criminals (Wheeler et al., 1988; Weisburd, 1991).

\section{Motivation}

The matter of motivation among white-collar criminals is related to the discussion of self-control. According to the general theory of crime, crime and social deviance are just two parts of the same coin and criminals are people with a propensity for antisocial conduct who lack social conformity (Gottfredson \& Hirschi, 1990). Empirical investigations have shown, however, that this postulation is not fully verified for white-collar criminals. The frequency of white-collar criminals with antisocial conduct problems is rather small (no more than 15\%) compared to street criminals where almost half have such conduct problems (Benson \& Moore, 1992; Lewis, 2002). Instead, white-collar criminals tend to conduct themselves in a similar manner as non-offenders indicating considerable self-control, not less (Shechory et al., 2011). Thus, the issue becomes a question of what the difference is for white-collar criminals when it comes to motivation (Benson \& Moore, 1992).

Greed is a commonly proposed factor behind white collar crime (Bucy, et al, 2008), but this is also a commonly disputed factor because the majority of white collar criminals are motivated to enhance the profits of their firm and not to primarily benefit themselves. In addition, if there is a personal reason to commit the crime the offender is usually more motivated to avoid losing than to gain for their own sake (Heath, 2008; Engdahl, 2010). Of course, this does not mean that financial gain is not important as a motivational factor (Bussmann \& Werle, 2006; Bucy et al., 2008). In fact, it has some undisputed empirical support in general (Dellaportas, 2013; Hollow, 2014). Financial gain is a significant factor if it is linked to psychological factors such as ethical flexibility, resilience, self-restraint, arrogance, and entitlement and to whether the individual has the capacity to cope with the pressure to achieve financial gain for themselves (to get and keep a good job, to be successful, etc.) or for the company they work for (to meet particular financial goals). In general, people can withstand such pressures, but those who cannot sometimes choose to cut the corners by adopting a coping strategy that prioritizes ethical flexibility, resilience, lower self-restraint, a higher degree of arrogance, entitlement, etc. (Shover \& Hochstetler, 2006; Shover, et al, 2012; Heath, 2008; Dellaportas, 2013). Even here there is a gendered division. Female offenders are mainly motivated by family reasons, and there is typically a non-financial pressure and a need-based justification that is often influenced by their close personal relationship with their male spouse or by occupying a strategic position within a company where they are manipulated by men (Daly, 1989; Steffensmeier et al., 2013).

Related to the discussion of motivation is the issue of personality (Listwan, et al, 2010; Cleff, 2013). There is consensus within the literature that some specific personality traits recur in white-collar criminality. A rather general observation is that white-collar criminals tend to have lower levels of conscientiousness, agreeableness, and self-restraint compared to white-collar professionals in general. In addition, white collar offenders also tend to be more anxious, 
neurotic, and extroverted than white collar professionals in general (Alalehto, 2003; Blickle et al., 2006; Collins \& Bagozzi, 1999; Collins \& Schmidt, 2006; Feeley, 2006; Ragatz \& Fremouw, 2010; Listwan et al., 2010).

A related issue to personality traits, but with significantly less empirical evidence to support it, is the issue of psychological disorders, especially the prevalence of psychopathies such as narcissism and Machiavellianism (Knecht, 2006; Ray \& Jones, 2011; Perri, 2011; Perri, 2013). Psychopathy is in general connected to antisocial conduct such as ruthless decision-making (callousness, grandiosity, and manipulation) and low self-control (impulsivity, irresponsibility, and poor behavioral control) (Pardue, et al, 2013b). Psychopathy appears to be overrepresented among corporate leaders (about 6\%) compared to the general public (about 1.5\%) (Babiak, et al, 2010). Research has shown a correlation between psychopathy (especially Machiavellianism, which describes people who are less ethically oriented) and white collar criminality (Poortinga et al., 2006; Ray \& Jones, 2011). There is also evidence for a significant correlation between narcissism and white collar criminality (Blickle et al., 2006; Perri, 2011). In general, however, the majority of white collar criminals do not suffer from psychological disorders (Heath, 2008).

Social influence as a motivational matter is related to situational factors that trigger the offenders (Piquero \& Benson, 2004), and these factors include the need for control, risk-option decision making, and fear of falling (Bucy et al., 2008; Shover et al., 2012). The need for control refers to individuals who are assertive, decisive, and active. They tend to be anxious neurotics who seek to control the situation both now and in the future. However, if their actions fail they will not take any responsibility for the failure or will blame the failure on external factors (Bucy et al., 2008). The empirical support for this approach is mixed and confusing. It is not clear that a need for control (futureoriented control) is unrelated to low self-control (here-andnow action) to determine if the intent to commit a crime was based on a need for control that is separate from low selfcontrol (Piquero, et al, 2005; Schoepfer, et al, 2014).

Risk-option decision making refers to individuals who foresee negative financial outcomes for their business and thus have a tendency to take more advanced risks. They can either be inspired by a role model or by stress leading to desperate actions (Shover et al., 2012). The empirical support for this is rather well established in terms of lowfrequency offenders who take advantage of a situation only when they perceive a crisis (Weisburd et al., 2001). Crisis responders make up the majority of white collar offenders (up to 70\%) (Piquero \& Weisburd, 2009) and this shows that if a crisis responder perceives a threat to something of high value it can influence them to embrace illegitimate means if no other options are available (Engdahl, 2011). A related structural condition for this hypothesis is the increase of women in the labor force since the 1980s and the increasing number of single mothers who are responsible for child rearing. These appear to be correlated to the increase in female white collar offenders during the same period because women now have greater responsibilities for both earning money and managing the living expenses for their families (Haantz, 2002).

Fear of falling refers to the fear of losing professional, financial, or social status. Studies have shown that individuals tend to defend their position by any means necessary to preserve their material and social wealth for themselves and their families (Bucy et al., 2008), but the empirical support for this is mixed. On one side, the fear of falling can have a tendency to deter instead of trigger the potential offender, i.e. the potential offender becomes more moralistic and risk avoiding and less benefit oriented than before (Piquero \& Piquero, 2011). On the other hand, investigations of female offenders show that they try to recover from family emergencies or to avoid poor family economic conditions by engaging in white collar crime, which is in contrast to the career motivation that is often seen in male offenders (Alalehto, 1999; Daly, 1989; Zietz, 1981). This indicates that there are less of non-financial pressures that lead to white collar crime (Dellaportas, 2013; Hollow, 2014).

A related topic to motivation is the rationalization or neutralization by the offenders. The research clearly shows that white-collar offenders often seem to be fully aware that they have performed an improper act, but not a criminal act. They do not associate themselves with a criminal lifestyle or criminal thinking; they are just ordinary people accused of something they cannot be responsible for. For this reason, white collar offenders often use rationalization ('I didn't steal it, I just borrowed it') (Cressey, 1953) or neutralization (by excusing: 'It was one-off incident' or by justifying: 'It was the right thing to do, considering the circumstances') (Sykes \& Matza, 1957) to legitimate their decisions (Azarian \& Alalehto, 2014; Benson, 1985; Benson \& Walker, 1988; Copes, 2003; Jacobsson, 2012; Klenowski et al., 2010; Shover, et al, 2003).

\section{Career Criminality}

In modern criminological research, the onset, duration, and desistance of the offender's criminal career have become the central issues in the topics of life-course and developmental theory (Farrington, 2008; Laub \& Sampson, 2003; Piquero, Farrington, \& Blumstein, 2007). The issue concerns the differences between the 'one-timer' and the career criminal (those with four or more convictions) concerning background, occupational career, family life, etc. The life-course approach has begun to catch on in investigations of street criminality, especially juvenile delinquency, but it has not yet reached the field of white collar crime to a significant degree (Piquero \& Benson, 2004).

The few investigations that discuss career criminality (Benson, 2002; Lewis, 2002; Soothill et al., 2012; Weisburd et al., 2001; Onna et al., 2014) show that only a small percentage of white collar criminals can be considered career criminals. Weisburd et al (2001) and Piquero and Weisburd (2009) classify $5 \%$ as 'chronic criminals', and Onna et al (2014) classify $4 \%$ as 'stereotypical criminals' with a crime rate of 2.3 per year compared to 0.41 crimes per year by 'adult-onset offenders'. Lewis (2002) and Soothill et al. (2012) show that less than $1 \%$ of career white collar 
criminals are 'pure' white collar criminals meaning that they have not mixed their criminality with any street criminality. However, among white collar criminals who mix white collar and street crime, $46 \%$ (Lewis, 2002) or 20\% (Soothill et al., 2012) of the selected population could be considered career criminals.

The characteristics of the career white collar criminal include engaging in a mix of white collar and street crime, being male, being younger (under 30 years), having a low education level, having two or more emotional or drugrelated problems, and living alone (Lewis, 2002; Soothill et al., 2012). It is especially notable that career white-collar criminals show lower self-control in general compared to career street criminals, and this distinguishes them categorically from one-time white-collar offenders (Weisburd et al., 2001:88). The characteristics of career white-collar offenders seem to be based on whether the white-collar criminal's first offense is a white-collar crime or a street crime. If it is a street crime, then this population consists more of young men who are ethnic minorities. For those who engage only in white-collar crime, the population consists predominantly of middle-aged white men (Lewis, 2002: 124-129).

The differences in the characteristics of career whitecollar criminals include the onset, duration, and desistance of the criminal behavior. Depending on whether the offender starts with a street crime or a white collar crime and if the offender sticks to only white collar crime or mixes it with street crime has a significant influence on the age-crime relationship. The onset of criminal behavior is usually younger if the offender mixes crimes and starts with street crime and is usually older if the offender is a 'pure' white collar criminal. The duration of the criminal behavior is on average 14.5 years, but this depends on many different factors. The offenders tend to stop their criminal behavior at around 50 years of age independent of the onset or duration of the criminal behavior (Onna et al., 2014; Weisburd et al., 2001).

\section{RESEARCH NEEDS}

From a thematic point of view, the number of longitudinal investigations into white collar criminals' life trajectories is still small compared to the number of lifecourse studies of street criminality (DeLisi \& Piquero, 2011). We do know that white-collar criminals diverge in several demographic characteristics from street criminals, but we do not know in any specific way how the life courses of whitecollar criminals diverge from those of non-offenders. The data on life-course approaches are lacking and cover aspects of the white collar criminal's life that are too vague to deduce any general empirical mechanisms. For example, there is strong evidence that low self-control is a central mechanism behind street criminality (e.g. DeLisi, 2001; Delisi, et al, 2003) but not for white collar criminality except for low complexity fraud carried out by men (Holtfreter $e t$ al., 2010). This is a disturbing situation concerning the research on white-collar criminals; we cannot credibly identify any central mechanism(s) that can be used to explain the divergence of white-collar criminals from non-offenders.
Another topic related to the lack of longitudinal investigations is the age-crime issue (Onna et al., 2014). White-collar criminals differ as a group with some criminals committing their crimes as adolescents and some in middle age, but the majority commit their crimes in late middle age. This difference is central to understanding the mechanism of why such crimes arise in general in late middle age and not before, especially if we compare this to street criminals. An important question to ask is why street crime peaks during adolescence but white-collar crime peaks in middle age. The research in this field has not yet provided any credible answers to this question (Shover \& Hochstetler, 2006:133).

Another topic of central relevance is the gendered differences seen in white-collar crime, especially the differences in whether the crime is of high or low complexity and the differences in motivation behind the criminality. Structural conditions such as an increasing number of women in the labor market combined with a greater responsibility for family seems to be a significant motivational push-factor. The increase of women in the labor market provides more opportunities for women to act criminally in general, and this is especially the case if they are motivated by stressful living conditions in taking care of their family. This is an aspect that should be more carefully investigated in the future.

A fourth topic of relevance is the rather poorly investigated field of motivations behind white-collar criminality. This is especially the case if we compare it to investigations of demographics and patterns of rationalization behind white collar criminality that provide many more specific details of the characteristics of white collar criminals and how they legitimate their crimes. This is actually rather surprising considering that in general the most interesting topic is the offender's motivation for engaging in white-collar crime.

\section{CONFLICT OF INTEREST}

The author confirms that this article content has no conflict of interest.

\section{ACKNOWLEDGEMENTS}

Declared none.

\section{REFERENCES}

Alalehto, T. (1999). Finns där ett kön bakom ekonomisk brottslighet? Retfärd. Nordisk Juridisk Tidsskrift, 22(2), 53-62.

Alalehto, T. (2003). Economic crime: does personality matter? international Journal of Offender Therapy and Comparative Criminology, 47(3), 335-355.

Alalehto, T.I., \& Persson, O. (2013). The Sutherland tradition in criminology: a bibliometric story. Criminal Justice Studies, 26(1), $1-18$.

Alalehto, T., \& Larsson, D. (2008). Vem är den ekonomiske brottslingen? En sociodemografisk profilstudie av 23 länder. In: Alalehto, T., \& Larsson, D. (eds), Den ljusskygga ekonomin: organiserad och ekonomisk brottslighet. Umeå: Umeå universitet.

Alalehto, T., \& Larsson, D. (2012). Who is the economic criminal?: a comparison between countries and types of crime. Sociologisk Forskning, 49(1), 25-44.

Azarian, R., \& Alalehto, T. (2014). Patterns in account-giving among white collar criminals. Deviant Behavior, 35(2), 101-115. 
Babiak, P., Neumann, C.S., \& Hare, R.D. (2010). Corporate psychopathy: Talking the walk. Behavioral Sciences \& the Law, 28(2), 174-193.

Benson, M.L. (1985). Denying the guilty mind: accounting for involvement in a white-collar crime. Criminology, 23(4), 583-607.

Benson, M.L. (2002). Crime and the life course: an introduction. Los Angeles, CA: Roxbury.

Benson, M.L. (2013). Editor's Introduction-White-Collar Crime Bringing the Offender Back In: Journal of Contemporary Criminal Justice, 29(3), 324-330.

Benson, M. L., \& Moore, E. (1992). Are White-collar and common offenders the same? An empirical and theoretical critique of a recently proposed general theory of crime. Journal of Research in Crime and Delinquency, 29(3), 251-272.

Benson, M.L., \& Walker, E. (1988). Sentencing the White-Collar Offender. American Sociological Review, 53(2), 294-302.

Blickle, G., Schlegel, A., Fassbender, P., \& Klein, U. (2006). Some personality correlates of business white-collar crime. Applied Psychology, 55(2), 220-233.

Bonger, W. (1969). Criminality and economic conditions. ( $1^{\text {st }}$ eds.) Hardback. Dust Jacket: Indiana University Press.

Braithwaite, J. (1985). White Collar Crime. Annual Review of Sociology, 11, $1-25$.

Brå - Brottsförebyggande rådet - Förebygga ekobrott, behov och metoder. Bilaga: enkätundersökning. (2003).

Bucy, P.H., Formby, E.P., Raspanti, M.S., \& Rooney, K.E. (2008). Why do they do it: the motives, mores, and character of white collar criminals. St. John's Law Review, 82, 401.

Bussmann, K.D., \& Werle, M.M. (2006). Addressing crime in companies. British Journal of Criminology, 46(6), 1128-1144.

Coleman, J.W. (1987). Toward an integrated theory of white-collar crime. American Journal of Sociology, 93(2), 406-439.

Collins, J.M., \& Bagozzi, R.P. (1999). Testing the equivalence of the socialization factor structure for criminals and noncriminals. Journal of Personality Assessment, 72(1), 68.

Collins, J.M., \& Schmidt, F.L. (2006). Personality, integrity, and white collar crime: a construct validity study. Personnel Psychology, 46(2), 295-311.

Copes, H. (2003). Societal attachments, offending frequency, and techniques of neutralization. Deviant Behavior, 24(2), 101-127.

Cressey, D.R. (1953). Other people's money: a study in the social psychology of embezzlement. Glencoe, Ill.: Free Press.

Croall, H. (1989). Who is the White-Collar Criminal? British Journal of Criminology, 29(2), 157-174.

Croall, H. (1992). White Collar Crime. Open University Press.

Croall, H. (2001). Understanding white collar crime. Buckingham [England]; Philadelphia: Open University Press.

Daly, K. (1989). Gender and varieties of white-collar crime. Criminology, 27(4), 769-794.

Delisi, M. (2001). It's all in the record: assessing self-control theory with an offender sample. Criminal Justice Review, 26(1), 1-16.

Delisi, M., Hochstetler, A., \& Murphy, D.S. (2003). Self-control behind bars: a validation study of the Grasmick et al. scale. Justice Quarterly, 20(2), 241-263.

DeLisi, M., \& Piquero, A.R. (2011). New frontiers in criminal careers research, 2000-2011: A state-of-the-art review. Journal of Criminal Justice, 39(4), 289-301.

Dellaportas, S. (2013). Conversations with inmate accountants: motivation, opportunity and the fraud triangle. Accounting Forum, 37(1), 2939.

Deng, X., Zhang, L., \& Leverentz, A. (2010). Official corruption during china's economic transition: historical patterns, characteristics, and government reactions. Journal of Contemporary Criminal Justice, 26(1), 72-88.

Duffield, G.M., \& Grabosky, P.N. (2001). The psychology of fraud. Australian Institute of criminology. Hämtad från http://www.anatomyfacts.com/Research/fraud.pdf

Edelhertz, H. (1970). The nature, impact and prosecution of white-collar crime. Washington.

Ekobrottsligheten och ekobrottslingarna i ett framtidsperspektiv. (2005).

Engdahl, O. (2011). White collar crime and informal social control: the case of "Crisis Responders" in the Swedish banking and finance sector. Sociology Mind, 01(02), 81-89.

Esping-Andersen, G., \& Wagner, S. (2012). Asymmetries in the opportunity structure. Intergenerational mobility trends in Europe. Research in Social Stratification and Mobility, 30(4), 473-487.
Farrington, D.P. (2008). Integrated Developmental and Life-Course Theories of Offending (Advances in Criminological Theory). Transaction Publishers.

Gagnon, S. (2008). L'évaluation de la structure de personnalité d'un échantillon de fraudeurs québécois judiciarisés.

Gottfredson, M. R., \& Hirschi, T. (1990). A general theory of crime. Stanford University Press.

Gottschalk, P., \& Glas $\varnothing$, L. (2013). Gender in white-collar crime: an empirical study of pink-collar criminals. International Letters of Social and Humanistic Sciences, (04), 22-34.

Haantz, S. (2002). Women and White Collar Crime. National White Collar Crime Center http://www. nw3c. org/downloads/women_wccl.pdf.

Heath, J. (2008). Business ethics and moral motivation: a criminological perspective. Journal of Business Ethics, 83(4), 595-614.

Hollow, M. (2014). Money, morals and motives: an exploratory study into why bank managers and employees commit fraud at work. Journal of Financial Crime, 21(2), 4-4.

Holtfreter, K. (Juli). Is occupational fraud "typical" white-collar crime? A comparison of individual and organizational characteristics. Journal of Criminal Justice, 33(4), 353-365.

Holtfreter, K., Beaver, K.M., Reisig, M.D., \& Pratt, T.C. (2010). Low selfcontrol and fraud offending. Journal of Financial Crime, 17(3), 295-307.

Hout, M. (2010). Intergenerational class mobility and the convergence thesis: reflections 25 years later. The British Journal of Sociology, 61, 221-224.

Häkkänen-Nyholm, H., \& Nyholm, J.-O. (2012). Psychopathy in Economical Crime, Organized Crime, and War Crimes. I H. Häkkänen-Nyholm \& J.-O. Nyholm (Reds), Psychopathy and Law (ss 177-200). John Wiley \& Sons, Ltd.

Ivancevich, J.M., Duening, T.N., Gilbert, J.A., \& Konopaske, R. (2003). Deterring white-collar crime. The Academy of Management Executive, 17(2), 114-127.

Jacobsson, K. (2012). Accounts of honesty: refuting allegations of bribery. Deviant Behavior, 33(2), 108-125.

Kankaanranta, T., \& Muttilainen, V. (2010). Economic crimes in the construction industry: case of Finland. Journal of Financial Crime, 17(4), 417-429.

Kardell, J., \& Bergqvist, M. (2009). Equal treatment in Swedish economic crime investigations: do professional specialization and the suspect's social background matter? Journal of Scandinavian Studies in Criminology and Crime Prevention, 10(2), 76-101.

Karstedt, S., \& Farrall, S. (2007). Law-abiding majority?: the everyday crimes of the middle classes. Centre for Crime and Justice Studies.

Kerley, K.R., \& Copes, H. (2004). The Effects of Criminal Justice Contact on Employment Stability for White-Collar and Street-Level Offenders. International Journal of Offender Therapy and $\begin{array}{lll}\text { Comparative } \quad \text { Criminology, } & 48(1), & 65-84 .\end{array}$ http://doi.org/10.1177/0306624X03256660

Klenowski, P.M., Copes, H., \& Mullins, C.W. (2010). Gender, identity, and accounts: how white collar offenders do gender when making sense of their crimes. Justice Quarterly, 28(1), 46-69.

Larsson, D., \& Alalehto, T. (2013). The Reaction towards white collar crime: when white collar crime matters. The Open Criminology Journal, 6(1), 1-9.

Laub, J.H., \& Sampson, R.J. (2003). Shared beginnings, divergent lives: delinquent boys to age 70. Cambridge, MA: Harvard University Press.

Leeper Piquero, N., Lyn Exum, M., \& Simpson, S.S. (2005). Integrating the desire-for-control and rational choice in a corporate crime context. Justice Quarterly, 22(2), 252-280.

Levi, M. (1993). White-Collar Crime: The British scene. Annals of the American Academy of Political and Social Science, 525, 71-82.

Levi, M., Burrows, J., Fleming, M.H., \& Hopkins, M. (2007). The Nature, Extent and Economic Impact of Fraud in the UK. London: ACPO.

Lewis, R.V. (2002). White collar crime and offenders: a 20-year longitudinal cohort study. San Jose: Writers club press.

Listwan, S.J., Piquero, N.L., \& Van Voorhis, P. (2010). Recidivism Among a White-Collar Sample: Does Personality Matter? Australian and New Zealand Journal of Criminology, 43(1), 156-174.

Menard, S., Morris, R.G., Gerber, J., \& Covey, H.C. (2011). Distribution and correlates of self-reported crimes of trust. Deviant Behavior, 32(10), 877-917.

Merzagora, I., Pennati, A., \& Travaini, G.V. (2014). Psychology and Psychopathology of White collar crime. In: Caneppele, S., \& 
Calderoni, F. (Eds), Organized Crime, Corruption and Crime Prevention (ss 169-177). Springer International Publishing.

Noll, J. (2014). Disparities in Punishment of White- and Blue-Collar Crimes in Austria (SSRN Scholarly Paper No. ID 2404425). Rochester, NY: Social Science Research Network.

Onna, J.H.R. van, Geest, V.R. van der, Huisman, W., \& Denkers, A.J.M. (2014). Criminal Trajectories of White-collar Offenders. Journal of Research in Crime and Delinquency, 0022427814531489. http://doi.org/10.1177/0022427814531489

Ouimet, G. (2011). Criminel en col blanc de grande envergure. Un renard bien cravaté. Psychologie Française, 56(4), 239-258. http://doi.org/10.1016/j.psfr.2011.10.003

Paquette, E. (2010). Des pensées criminelles et des traits de personnalité de fraudeurs incarcérés, sous l'angle de la psychopathie.

Pardue, A.D., Robinson, M.B., \& Arrigo, B.A. (2013a). Psychopathy and corporate crime: a preliminary examination, Part 1. Journal of Forensic Psychology Practice, 13(2), 116-144. http://doi.org/10.1080/15228932.2013.765745

Pardue, A.D., Robinson, M.B., \& Arrigo, B.A. (2013b). Psychopathy and corporate crime: a preliminary examination, Part 2. Journal of Forensic Psychology Practice, 13(2), 145-169. http://doi.org/10.1080/15228932.2013.765746

Piquero, A.R., Farrington, D.P., \& Blumstein, A. (2007). Key issues in criminal career research: new analyses of the Cambridge Study in Delinquent Development. New York: Cambridge University Press.

Piquero, A.R., \& Piquero, N.L. (2011). The Only Thing We Have to Fear Is Fear Itself: Investigating the Relationship Between Fear of Falling and White-Collar Crime. Crime \& Delinquency, 58, 362-379.

Piquero, N.L., \& Benson, M.L. (2004). White-Collar Crime and Criminal Careers. Journal of Contemporary Criminal Justice, 20(2), 148165.

Piquero, N.L., \& Weisburd, D. (2009). Developmental Trajectories of White-Collar Crime. In: Simpson, S. S., \& Weisburd, D. (Eds), The Criminology of White-Collar Crime (ss 153-171). Springer New York.

Pontell, H.N., \& Calavita, K. (1993). White-collar crime in the savings and loan scandal. The ANNALS of the American Academy of Political $\begin{array}{lll}\text { and Social Science, } & \text { 525(1), }\end{array}$ http://doi.org/10.1177/0002716293525001003

Poortinga, E., Lemmen, C., \& Jibson, M.D. (2006). A Case control study: white-collar defendants compared with defendants charged with other nonviolent theft. J Am Acad Psychiatry Law, 34(1), 82-89.

Poveda, T.G. (1994). Rethinking white-collar crime. Praeger Westport, CT.

Punch, M. (1996). Dirty Business: Exploring Corporate Misconduct: Analysis and Cases. SAGE.

Ragatz, L., \& Fremouw, W. (2010). A critical examination of research on the psychological profiles of white-collar criminals. Journal of Forensic Psychology Practice, 10(5), 373-402.

Riemer, S.H. (1941). Embezzlement: Pathological Basis. Journal of Criminal Law and Criminology (1931-1951), 32(4), 411-423.

Ring, J. (2003). Skattefifflare och tjuvar. En studie av sociala förhållanden och brottsbelastning hos två grupper av gärningsmän.

Ross, E.A. (1973). Sin and Society. Harper \& Row.

Schnatterly, K. (2003). Increasing firm value through detection and prevention of white-collar crime. Strategic Management Journal, 24(7), 587-614. http://doi.org/10.1002/smj.330

Schoepfer, A., \& Piquero, N.L. (2006). Exploring white-collar crime and the American dream: A partial test of institutional anomie theory.
Journal of Criminal Justice, 34(3), 227-235. http://doi.org/10.1016/j.jcrimjus.2006.03.008

Shechory, M., Perry, G., \& Addad, M. (2011). Pathways to women's crime: differences among women convicted of drug, violence and fraud offenses. The Journal of Social Psychology, 151(4), 399-416. http://doi.org/10.1080/00224545.2010.503721

Shover, N., Coffey, G.S., \& Hobbs, D. (2003). Crime on the line. telemarketing and the changing nature of professional crime. British Journal of Criminology, 43(3), 489-505. http://doi.org/10.1093/bjc/43.3.489

Shover, N., \& Hochstetler, A. (2006). Choosing white-collar crime. Cambridge University Press.

Shover, N., Hochstetler, A., \& Alalehto, T. (2012). Choosing White-Collar Crime. In: Cullen, F.T. \& Wilcox, P. (Eds), The Oxford Handbook of Criminological Theory. Oxford University Press.

Simon, D.R. (1999). Elite deviance. Boston: Allyn and Bacon.

Simpson, S.S. (2013). White-Collar Crime: A Review of Recent Developments and Promising Directions for Future Research. Annual Review of Sociology, 39(1), 309-331. http://doi.org/10.1146/annurev-soc-071811-145546

Simpson, S.S., \& Weisburd, D. (2009). The Criminology of White-Collar Crime. Springer.

Slapper, G., \& Tombs, S. (1999). Corporate Crime. Longman Group United Kingdom.

Soothill, K., Humphreys, L., \& Francis, B. (2012). Middle-class offenders a 35-year follow-up. British Journal of Criminology, 52(4), 765-785.

Steffensmeier, D. J., Schwartz, J., \& Roche, M. (2013). Gender and TwentyFirst-Century Corporate Crime: Female Involvement and the Gender Gap in Enron-Era Corporate Frauds. American Sociological Review, 78(3), 448-476. http://doi.org/10.1177/0003122413484150 .

Sutherland, E.H. (1940). White-Collar criminality. American Sociological Review, 5(1), 1-12.

Sutherland, E.H. (1985). White Collar Crime: The Uncut Version. Yale University Press.

Sykes, G.M., \& Matza, D. (1957). Techniques of neutralization: a theory of delinquency. American Sociological Review, 22(6), 664-670.

The 2005 National Public Survey on White Collar Crime, 2006. (2006). National white collar crime center.

Vaughan, D. (1983). Controlling unlawful organizational behavior : social structure and corporate misconduct. Chicago: The University of Chicago Press.

Walters, G.D., \& Geyer, M.D. (2004). Criminal thinking and identity in male white-collar offenders. Criminal Justice and Behavior, 31(3), 263-281.

Weisburd, D. (1991). Crimes of the middle classes: White-collar offenders in the federal courts. Yale University Press.

Weisburd, D., Waring, E.J., \& Chayet, E. (2001). White-collar crime and criminal careers. Cambridge University Press.

Wheeler, S., Weisburd, D., Waring, E., \& Bode, N. (1988). White Collar Crimes and criminals. American Criminal Law Review, 25(3), 27.

Who is a Typical Fraudster?| KPMG | ZM. (2011, november 26).

Yaish, M., \& Andersen, R. (2012). Social mobility in 20 modern societies: The role of economic and political context. Social Science Research, 41(3), 527-538. http://doi.org/10.1016/j.ssresearch.2011.12.001

Zietz, D. (1981). Women who embezzle or defraud: A study of convicted felons. Praeger Publishers New York.

(C) T. Alalehto; Licensee Bentham Open.

This is an open access article licensed under the terms of the Creative Commons Attribution Non-Commercial License (http://creativecommons.org/licenses/ by-nc/3.0/) which permits unrestricted, non-commercial use, distribution and reproduction in any medium, provided the work is properly cited. 